\title{
中波放送波による送電線への誘導電界の低減 （架空地線を含む共振構造の場合）
}

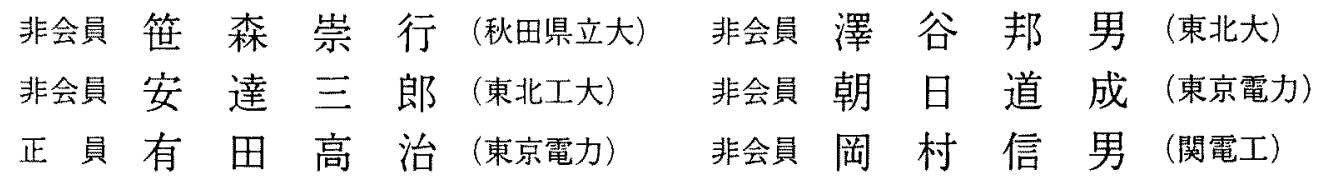

\section{Reduction of Induced Electric Field on Power Lines Due to Resonance of MW Broadcasting Wave}

\begin{abstract}
Takayuki Sasamori, Non-member (Akita Prefectural University), Kunio Sawaya, Non-member (Tohoku University), Saburo Adachi, Non-member(Tohoku Institute of Technology), Michinari Asahi, Non-member (Tokyo Electric Power Co.), Kohji Arita, Member (Tokyo Electric Power Co.), Nobuo Okamura, Non-member (Kandenko Co.)
\end{abstract}

It has been pointed out that a very strong electromagnetic field is induced occasionally along aerial power lines located near a medium wave (MW) broadcasting station, and the construction and the maintenance of power lines are sometimes endangered. We have presented a method to predict a dangerous span before the construction and the maintenance, and a use of a loading of appropriate inductor to decrease the induced field the case where the resonant loop is composed of three power lines, i. e., a top conductor, a middle conductor and a bottom conductor and part of towers.

In this paper, the effect of loading inductor for the case that the resonant loop includes a ground wire is presented. Since the ground wire is connected directly to the tower, the inductor can not be loaded into the ground wire. It is shown that the field strength in the vicinity of three power lines can be suppressed by loading the inductor to three power cables each. However, the field in the vicinity of the ground wire can not be suppressed significantly. Measured values of the field strength in the vicinity of the bottom conductor is presented to confirm the suppression effect.

キーワード：モーメント法，送電線，放送波，誘導電界， インダクタ

Keywords: method of moment, power line, broadcasting wave, induced electric field, inductor

\section{1.まえがき}

架空送電線の工事や保守作業を行うとさには作業回線の 送電を停止するが，作業をしない回線については作業中も 送電を継続しているのが一般的である。この送電回線を流 れる電流によって，作業回線には商用周波数の電磁誘導電 圧が発生する。これによる感電事故を防止するために，作 業回線の電線を一定区間ごとに両端の鉄塔に接地して工事 や保守作業が行われている。しかしながら，ラジオやテレ ビの放送所の近傍にある送電線では，接地された鉄塔間の 送電線に大きな高周波電界が誘導される場合があること が，以前から指摘されてきた(1)。

筆者らは，作業を行う前に危険な径間を数值解析により 子測する方法を示し，大きな誘導電界が共振によって発生

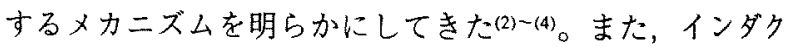
夕を用いて商用周波数と高周波による誘導電界を同時に低 减する方法を提案し，上楾，中線，下線の 3 本の電線に よって構成されるループが共振している径間について,こ の誘導低減方法が有効であることを数值計算と測定によっ て示した(5)ー(9)。これら3本の電線は, 通常の送電中の状態 ではがいしによって電線と鉄塔が絶緑状態になっているた め, 電線と鉄塔の間に容易にインダクタを取り付けること ができる。しかしながら，送電鉄塔の塔頂部に張られてい る架空地線については，常に鉄塔に接続されている構造 上，インダクタを取り付けるのが困難である。従って， ループに架空地線が含まれる場合にも 3 本の電線にインダ クタを取り付けることになるが，その効果については検討 されていない。

そこで本論文では，文献(2)～(9)とは異なり，放送波に よって共振するループに架空地線が含まれる径間を取り上 げ，架空地線以外の 3 本の電線にインダク夕を取り付けた 場合の誘導電界の低減効果について検討する。まず，本論 文で取り扱う径間の概要について説明し，次にその径間の 
接地時における電界強度の周波数応答及び，共振電流分布 を数值計算によって求め，その径間の共振構造を明らかに する。また，誘導電界を低減するためのインダクタンス值 を明らかにするために，電界強度のインダクタンス特性を 数値計算によって明らかにする。最後に，通常の接地状態 の場合とインダクタを用いて接地した場合について，電界 強度を測定した結果を数值計算結果とともに示す。

\section{2. 径間の概要}

中波ラジオ放送波によって大きな誘導電界が発生する径 間付近の放送用アンテナと送電線の配置図を図 1 に示す。 文献(4)，(9)では鉄塔1と鉄塔 2 の径間 (鉄塔間距離 $=212 \mathrm{~m}$ )に ついて解析と実験を行ったが，本論文では鉄塔3と鉄塔4の 径間 (鉄塔間距離 $=202 \mathrm{~m}$ )を取り上げる。この径間では，通 常 2 回線で154kVの送電が行われており，放送波によって大 きな誘導電界が発生することが経験的に知られている。表 $1 に は こ の ~ 2$ 基の鉄塔の高さ，送電線の位置，近傍にある 2 カ所の放送アンテナまでの距離及び鉄塔間の距離を示 す。この表に示すように2 カ所のアンテナは，この径間か ら600m以内と近い位置にある。表 2 にはこの 2 力所の放送 アンテナの周波数, 出力及びアンテナ高を示す。本論文で は, アンテナ 1 とアンテナ 2 から送信される放送波をそれ ぞれ放送波 1，放送波 2 と呼ぶことにする。なお，放送波 2 は国内では最大出力の中波放送波の一つである。

図 2 には，インダクタを用いた商用周波数と放送波の誘 導電界を同時に低減する方法を示す。インダクタを鉄荅の 腕金上に固定し，インダクタの片方の端子を鉄塔に接続す る。もう一方の端子は，接地線を用いてジャンパー線に接 続する。インダクタは，商用周波数の様な低周波数ではイ ンピーダンスが小さいので送電線を直接接地している状態 に近い。一方，ラジオ放送波ではインピーダンスが大きく なり，送電線と鉄塔を絶縁した状態に近くなる。このよう にして,インダクタにより商用周波数とラジオ放送波の両 周波数における誘導電界を低减する。

\section{3. 数值シミュレーション}

$<3 \cdot 1>$ 数值解析手法と計算モデル＼cjkstart本論文では，送 電線や架空地線に誘導する電界や電流を数值的に解析する ために文献(4)，(9)と同様にRichmondのモーメント法(10)を用 いる。解析モデルと座標系を図 3 に示す。座標系は，放送 用アンテナの給電点を原点にして，放送用アンテナと鉄塔 3 を結ぶ線をx軸にしている。また，解析モデルは図に示す ように構造を簡略化した。中波放送の周波数帯において大 地は完全導体と見なせるものとして，数值計算では大地に よる電気影像を考慮した上下対称の計算モデルとして取り 扱う。計算モデルの分割数は影像を含めて放送アンテナを 9 分割, 鉄塔を17分割, 架空地線と送電線をそれぞれ11分 割として，鉄塔と架空地線及び送電線との間に接続セグメ ントを16カ所設けて合計147個のセグメントに分割した。

電界の観測点の位置として，3本の電線及び架空地線の

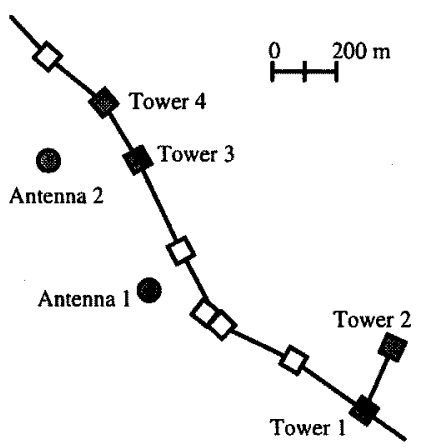

図 1 送電線とアンテナの配置

Fig. 1. Location of power lines and antennas.

表 1 鉄塔の諸元

Table 1. Dimensions of towers.

\begin{tabular}{c|c|c}
\hline & Tower 3 & Tower 4 \\
\hline Height of tower & $65.9 \mathrm{~m}$ & $57.9 \mathrm{~m}$ \\
\hline Height of top wire & $61.4 \mathrm{~m}$ & $53.4 \mathrm{~m}$ \\
\hline Height of middle wire & $56.2 \mathrm{~m}$ & $48.2 \mathrm{~m}$ \\
\hline Height of bottom wire & $51.0 \mathrm{~m}$ & $43.0 \mathrm{~m}$ \\
\hline Distance from antenna 1 & $395 \mathrm{~m}$ & $583 \mathrm{~m}$ \\
\hline Distance from antenna 2 & $277 \mathrm{~m}$ & $245 \mathrm{~m}$ \\
\hline Length of span & \multicolumn{2}{|c}{$202 \mathrm{~m}$} \\
\hline
\end{tabular}

表 2 放送用アンテナの諸元

Table 2. Dimensions of broadcasting antennas.

\begin{tabular}{l|c|c|c}
\hline & Frequency & Power & Height of antenna \\
\hline Antenna 1 & $594 \mathrm{kHz}$ & $300 \mathrm{~kW}$ & $245 \mathrm{~m}$ \\
\hline Antenna 2 & $693 \mathrm{kHz}$ & $500 \mathrm{~kW}$ & $215 \mathrm{~m}$ \\
\hline
\end{tabular}

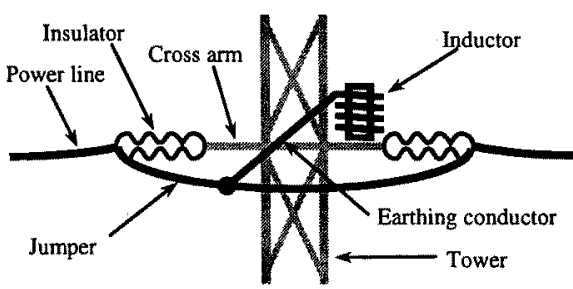

図 2 インダクタの取り付け方 Fig. 2. Loading inductor.

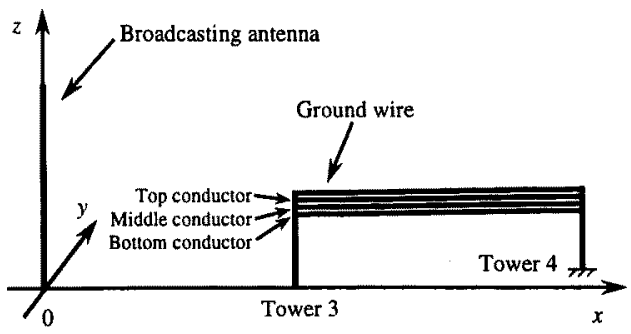

図 3 解析モデルと座標系

Fig. 3. Coordinate system and geometry of analysis.

各中心から下方向に $24 \mathrm{~cm}$, 水平方向に $11 \mathrm{~cm}$ の位置で各線と 平行な観測線上とし，この位置における全電界の $\mathrm{z}$ 成分を 計算する。これは第 4 章において述べるように，電界測定 
で得られる値と比較するためである。なお，上記の観測線 上における入射電界の最大值は，放送波1と2がそれぞれ $9.1 \mathrm{~V} / \mathrm{m}, 15.5 \mathrm{~V} / \mathrm{m}$ であった。

$<3 \cdot 2>$ 周波数特性 3 本の電線を両鉄塔に接地した ときの, 電線及び架空地線近傍の電界強度 $\left|\mathrm{E}_{\mathrm{z}}\right|$ の周波数特性 を図 4 に示す。ここで入射する放送波は，アンテナ2の地 点から出力 $500 \mathrm{~kW}$ 周波数を变化させて送信されているも のとする。また，アンテナ長は送信周波数の波長に合せて 長さが 0.58 波長となるように変化させた。

図4に，3本の送電線及び架空地線近傍の電界の計算値の

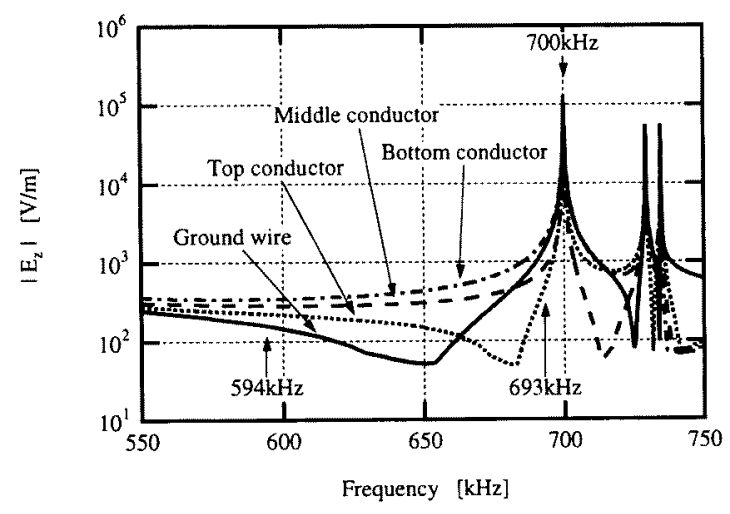

図 4 電界強度 $\left|\mathrm{E}_{z}\right|$ の周波数特性

Fig. 4. Frequency characteristics of field strength $\left|E_{2}\right|$.

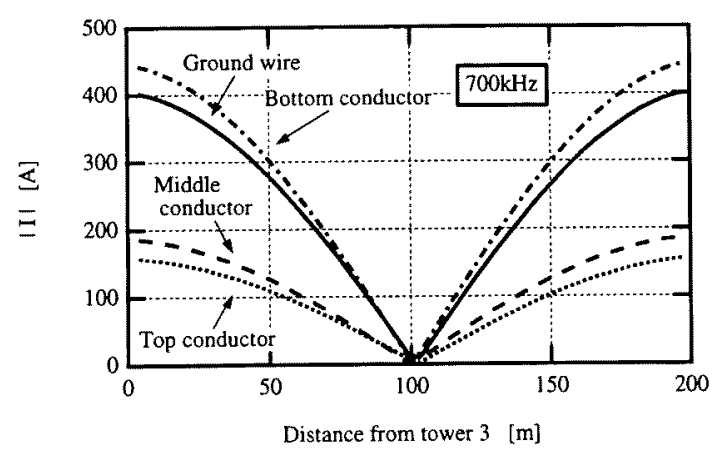

(a)

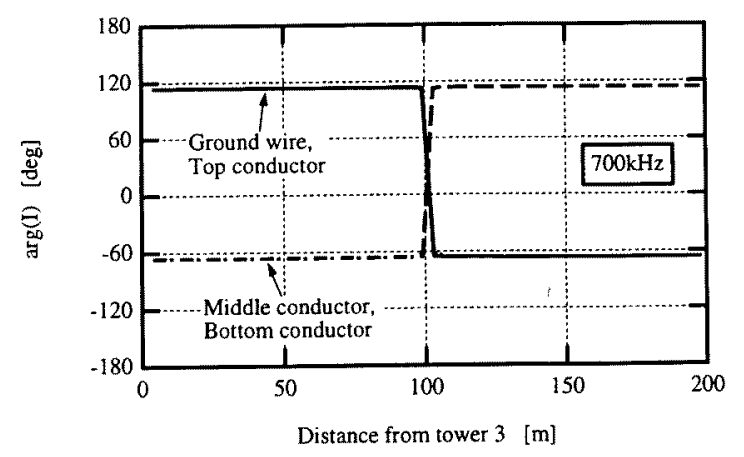

(b)

図 5 誘導電流の振幅と位相

Fig. 5. Induced current.
うち最大值を示す。両放送波の周波数において電界強度が 最大となるのは下線近傍であり，その值は放送波 1 と 2 が それぞれ343.0V/mと $1919 \mathrm{~V} / \mathrm{m}$ である。また，電界が最大值 となる共振周波数は $700 \mathrm{kHz} ゙$ あ，このとき架空地線と下 線近傍の電界強度は $100 \mathrm{kV} / \mathrm{m}$ 以上になる。

$<3 \cdot 3>$ 電流分布 大きな誘導電界が発生する共振構 造を明らかにするため，共振周波数における誘導電流の振 幅と位相を求める。周波数 $700 \mathrm{kHz}$, 出力 $500 \mathrm{~kW}$ で放送波が 送信されているときに，3本の電線及び架空地線上を流れ る高周波電流の振幅と位相をそれぞれ図 $5(a)$, (b)に示す。 図 5 (a)加，誘導電流は主に架空地線と下線を流れてお り，上線と中線を流れる電流は架空地線と下線を流れる電 流の半分以下であることがわかる。また，図 5 (b)に示す通 り，架空地線と上線を流れる電流が同位相で，中線と下線 を流れる電流の位相はそれらと逆であることから，これら に誘導される電流分布は図 6 に示すようになる。周波数 $700 \mathrm{kHz}$ の1波長は428.6mであるのに対して，架空地線と下 線及び鉄塔の一部から構成されるループは436.1mであるこ とから、このループはほほ 1 波長で共振していることがわ かる。

<3・4>インダクタンス特性インダクタンスによる 誘導電界の低隇効果を明らかにするために，3個の同じイ ンダクタを 3 本の電線と鉄塔の接続部分に1個ずつ取り付 け，各送電線及び架空地線近傍の電界強度を求めた。その 結果を図 7 (a) と(b)に示す。これらの図から，3本の電線近 傍の電界強度については，例えば600 $\mathrm{H} \mathrm{H}$ 以上のインダク夕 ンスを選ぶことにより放送波 1 と放送波 2 の両方の放送波 に对して全ての電線を $100 \mathrm{~V} / \mathrm{m}$ 以下に低減できることがわか る。なお，日本の電波防護指針では，該当する周波数の電 磁界強度の指針值は管理環境で $614 \mathrm{~V} / \mathrm{m}$, 一般環境で $275 \mathrm{~V} / \mathrm{m}$ となっている(11)。一方，架空地線について電界強度を $100 \mathrm{~V} /$ m以下に低減できるインダクタンス值を求めると，図 7 (a)

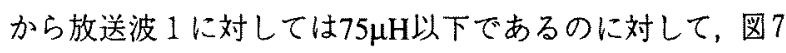

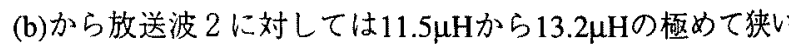
範囲だけであることがわかる。このように，図6に示すよ うな共振の周波数近傍では，インダクタを取り付けていな い架空地線については，放送波 2 にる誘導電界を低減す るのが困難であることがわかる。また，次章の測定で用い

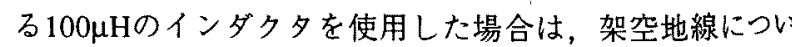
ては放送波 1 と放送波 2 に対する電界強度がそれぞれ94.6V/ $\mathrm{m}, 930 \mathrm{~V} / \mathrm{m}$ であり，3 本の電線については放送波 1 と放送

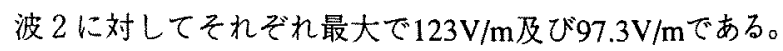

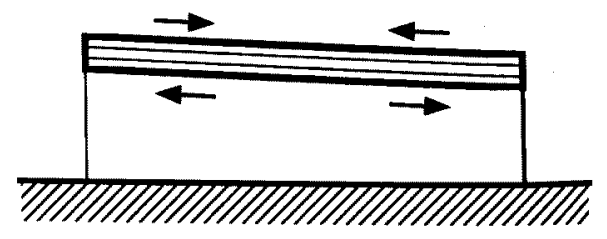

図 6 電流分布の概要

Fig. 6. Schematic illustration of current distribution. 


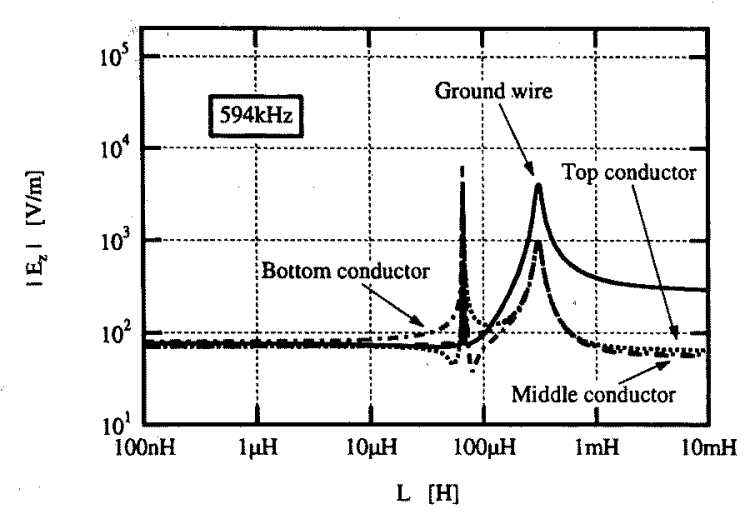

(a)

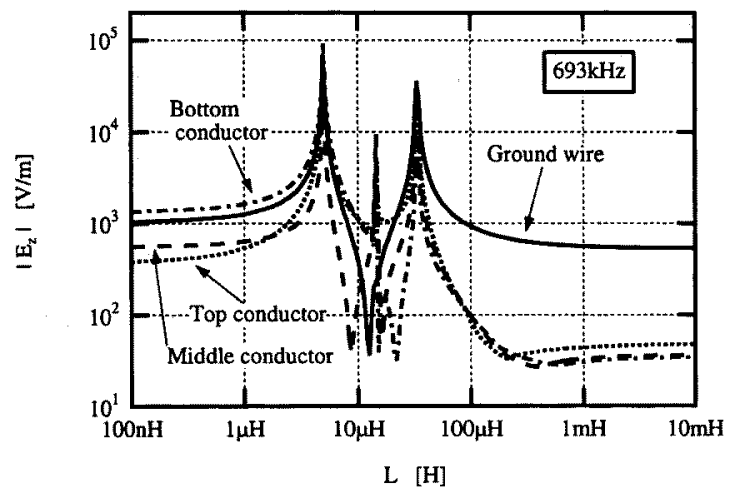

(b)

图7インダクタンス值に対する送電線及び架空地線近傍 の電界強度 $\left|\mathrm{E}_{2}\right|$

Fig. 7. Field strength $\left|E_{z}\right|$ in vicinity of power lines and ground wire versus inductance.

\section{4. 実測結果}

本径間において送電線近傍の電界強度を測定した結果に ついて述べる。電界プローブは台車に垂直に固定し，この 台車を下線に吊り下げ移動させることにより，電線に沿っ て電界を測定した。電界プローブの給電点の位置は下線の 中心から下方向に $24 \mathrm{~cm}$, 水平方向に $11 \mathrm{~cm}$ である。また, 電 線に吊り下げた電界プローブと地上の測定器を結ぶケーブ ルが電界を乱すのを避けるために, 光ファイバケーブルを 使用した。

始めに，3本の電線を鉄塔に接地した状態における下線 近傍の電界 $\left|\mathrm{E}_{2}\right|$ の測定結果を計算值と共に図 8 に示す。放送 波 1 の周波数では, 電界の最大值は測定値が $114 \mathrm{~V} / \mathrm{m}$, 計算 值が $81.6 \mathrm{~V} / \mathrm{m}$ である。一方，放送波 2 の周波数では，電界の 最大值は測定值が $1096 \mathrm{~V} / \mathrm{m}$, 計算值で $1330 \mathrm{~V} / \mathrm{m}$ となり, 大き な值であることがわかる。测定值と計算值が合わない原因 としては, 電界の測定には微小ダイポールアンテナを使用 しており，この校正が必ずしも十分ではないなどの理由か ら発生した測定誤差や，計算に用いたモデルが簢略化モデ ルであるため, 計算值についても誤差が含まれていること が考えられる。特に放送波 2 の周波数で大きく異なる值と

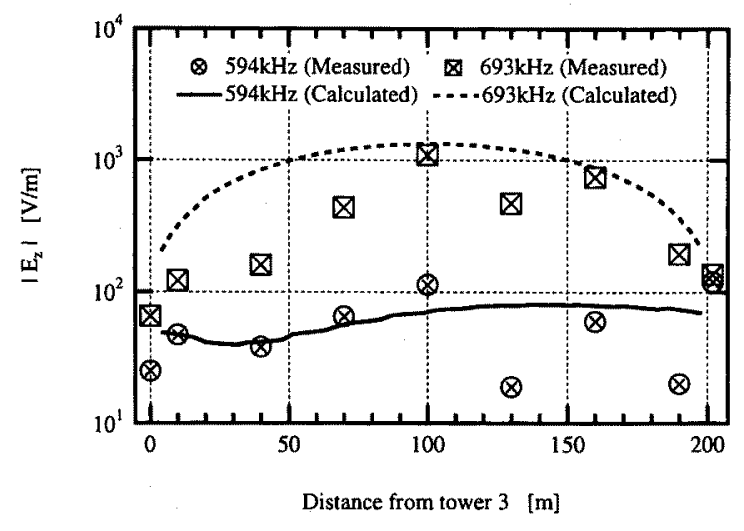

図 8 通常接地のときの下線近傍電界強度 $\left|\mathrm{E}_{\mathrm{z}}\right|$ Fig. 8. Field strength $\left|E_{z}\right|$ for regular short.

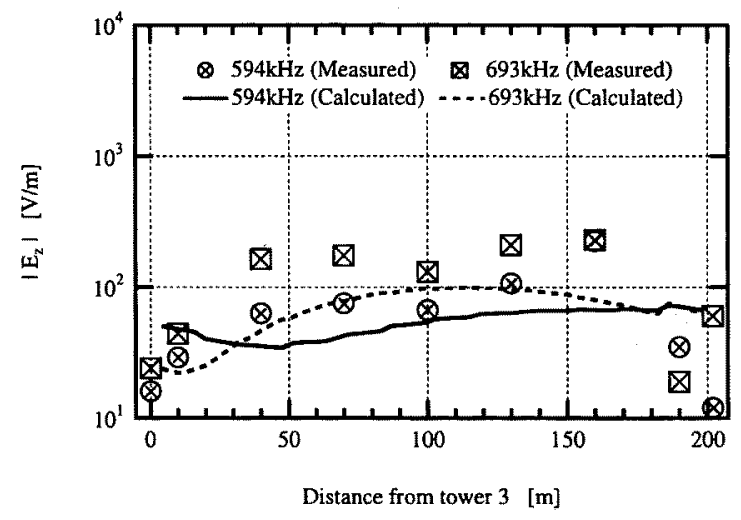

図 9 インダクタンスを用いたときの下線近傍電界強度 $\left|\mathrm{E}_{\mathrm{z}}\right|$

Fig. 9. Field strength $\left|E_{z}\right|$ in vicinity of bottom conductor using inductance.

なっているのは，図4からわかるように回路の良さQが大き な共振が発生しているために，計算モデルの誤差が電界の 值の大きな誤差をもたらすためであると考えられる。

次に，インダクタを取り付けた状態に扔ける下線近傍の 電界 $\left|\mathrm{E}_{2}\right|$ の測定結果を計算值と共に図 9 に示す。インダクタ ンス值は, 放送波 2 にる 3 本の電線近傍の電界を約 $100 \mathrm{~V} /$

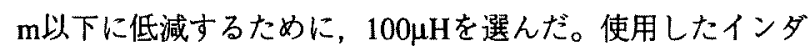
ク夕は，鉄塔 1 と鉄塔 2 の径間における測定のときに使用 したものと同じである。放送波 1 の周波数では，電界の最 大值は測定値が $226 \mathrm{~V} / \mathrm{m}$ ，計算值が75.0V/mである。一方， 放送波 2 の周波数では，電界の最大值は測定值が $232 \mathrm{~V} / \mathrm{m}$, 計算值で $100 \mathrm{~V} / \mathrm{m}$ であった。このように，インダクタを用い て接地することにより，下線近傍については放送波による 誘導を低滅できることが確認できた。

\section{5、まとめ}

本論文では，放送波によって大きな誘導電界が発生する 径間のうち共振構造に架空地線を含む径間を取り上げ，イ ンダク夕装荷による誘導の低减効果について検討した。

始めに，ラジオ放送波によって誘導電界が発生する径間 において，誘導電界強度の周波数特性を数值計算によって 
求め，共振周波数が放送波 2 とほほ一致することを示し た。次に，架空地線と 3 本の電線を流れる誘導電流分布を 数值計算によって求めた。その結果, 架空地線と下線とそ れらを支える鉄塔の一部が，放送波 2 に対してほほ 1 波長 のループを構成して大きな誘導電流が流れることを明らか にした。また，架空地線と 3 本の電線の近傍で観測される 電界強度のインダクタンス特性を数值計算によって求め, 3 本の送電線については誘導電界を抑圧することができる が, 架空地線近傍の電界を十分に抑圧することは困難であ ることを示した。最後に, 通常の接地の場合とインダクタ を用いて接地した場合について下線近傍の電界強度を測定 した結果を示し，インダクタを用いて誘導電界を低隇する 方法の効果を確認した。

本論文によって, 共振構造に架空地線を含む径間につい てもインダクタを用いて接地する方法が有効であることを 明らかにした。インダクタを取り付けることが困難な架空 地線の誘導低減対策を明らかにすることが，今後の検討課 題である。

(平成 13 年 4 月 9 日受付, 10 月 15 日再受付)

\section{文献}

（1）小川正浩·松本良一，西山光生 - 井口勝弘：「中波放送所近傍の強 電磁界内を通過する送電線への誘導特性と線路保守」，電学電力 エネルギー部門大会, 2 , pp. 317-318(1995-8)

(2) 笹森崇行 · 神成真利 - 澤谷邦男 ·安達三郎 - 小川正浩 - 西山光 生・井口勝弘：「中波放送波によって送電線と鉄荅付近に誘起され る電磁界」, 1996信学総大, B-273(1996-3)

（3）笹森崇行・澤谷邦男・安達三郎・村井泰仁 - 小川正浩 - 井口勝 弘・西山光生：「中波放送波によって送電線付近に誘起される電磁 界一共振現象の解析一」, 1997信学棇大, B-4-31(1997-3)

（4）笹森崇行 - 澤谷邦男·安達三郎・村井泰仁 - 小川正浩 - 井口 勝弘 - 西山光生 :「中波放送波による送電設備への誘道の解析」, 信学論(B), J82-B, 4, pp. 645-652(1999-4)

(5) 笹森崇行. 神成真利 · 䐾谷邦男 - 安達三郎 - 小川正浩 - 西山光 生・井口勝弘：「中波放送波によって送電線近傍に誘起される電磁 界の解析」，信学技報， EMCJ 96-1，pp. 1-6(1996-4)

(6) 村井泰化 - 小川正浩 - 西山光生 · 井口勝弘 - 笹森崇行 - 䐾谷邦 男・安達三郎:「中波放送波に上る送電線への誘起電界の低減对策 に関する検討」１996電学電力・エネルギー部門大，E-202，pp. 468-469(1996-8)

(7) 笹森崇行 - 澤谷邦男 - 安達三郎 ·村井泰仁 - 小川正浩 - 西山光 生・井口勝弘：「中波放送波によって送電線付近に誘起される電磁 界ーインダクタンス装荷による抑圧一」，1996信学ソ大，B-271 (1996-9)

（8）村井泰仁 - 小川 正浩 - 西山 光生 · 井口勝弘 - 笹森崇行 · 澤谷 邦男・安達三郎：「送電線への中波放送波誘起電界の低隇方法に 関する検討」，信学技報，EMCJ 96-39， MW 96-91， pp. 23-28 (1996-10)

(9) 笹森崇行 · 澤谷邦男 · 安達三郎 - 村井泰仁 - 小川正浩 - 西山光 生・井口勝弘：「インダクタンス装荷による中波放送波の送電線へ の誘導の抑圧」, 信学論(B)，J84-B，2，pp. 283-290(2001-2)

(10) J. H. Richmond and N. H. Greary, "Mutual Impedance of NonplanarSkew Sinusoidal Dipoles," IEEE Trans. Antennas Propagat., Vol. AP23, No. 3, pp. 412-414(1975-5)

(11) 電気通信技術審議会答申：「電波利用における人体の防護指針」 (1990-6)

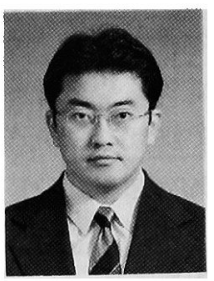

笹 森 崇 行 (非会員) 1966年11月22日 生。1989年3月東北大学工学部電気工学科卒業。 1994年同大学大学院工学研究科電気及通信工学専 攻博士課程修了。同年5月同大学工学部助手。 1996年4月仙台電波高専講師。1999年4月秋田県立 大学講師, 現在に至る。博士(工学)。電磁波の散 乱・回折, 移動体通信用アンテナ, 送電線への誘 導の研究に徒事。1997年電子情報通信学会学術奖励賞受賞。電子情報 通信学会, IEEE会員。

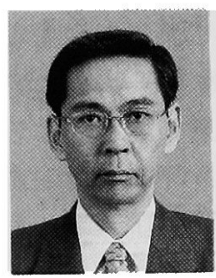

澤 谷 邦 男 (非会員) 1949年2月21日 生。1971年3月東北大学工学部通信工学科卒業。 1976年同大学大学院工学研究科電気及通信工学専 攻博士課程修了。現在, 同大大学院工学研究科電 気・通信工学専攻教授。プラズマ中のアンテナ, 移動通信用アンテナ, 電磁波の散乱・回折, ア レーアンテナ, プラズマ加熱用アンテナ, 超伝導 アンテナの研究に従事。工学博士。1981年電子通信学会学術奖励賞, 1988年電子情報通信学会論文賞受賞。

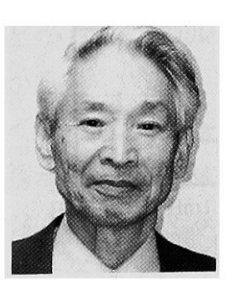

安 達三郎 (非会員) 1930年9月2日生。 1953年3月東北大学工学部通信工学科卒業。1958 年同大学大学院工学研究科電気及通信工学専攻博 士課程修了。以来, 今日に至るまで電磁波工学、 ならびにプラズマ波動理工学に関する研究に従 事。現在, 東北工業大学教授, 東北大学名誉教 授。工学博士。電子情報通信学会功績賞他各賞を 授賞，IEEEフェロー，日本工学アカデミー会員，著書「電波伝送工学 (共著)」,「電磁波工学」,「電磁気学」等多数。

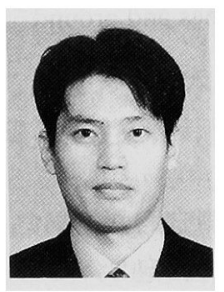

朝日道 成 (非会員) 1967年11月2日 生。1990年3月東京農工大学工学部電子工学科卒 業。同年4月東京電力(株)入社。主として, 架空送 電線設備の設計・研究業務に従事。現在, 同社春 日部工務所勤務。

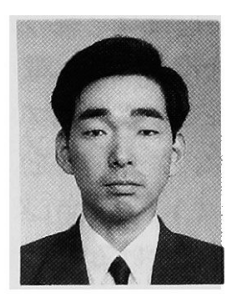

有田高治（正員）1963年10月6日生。 1986年3月千葉工業大学工学部電気工学科卒業。 同年東京電力 (株) 入社。主として, 架空送電設㣁 の設計, 研究業務に従事。現在, 同社埼玉支店工 務部送電グルーブ勤務。

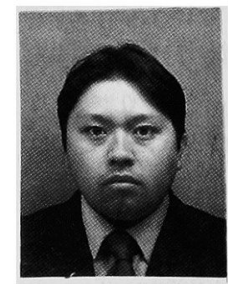

岡 村 信 男 (非会員) 1973年1月24日 生。1995年3月宇都宮大学工学部電気電子工学科 卒業。同年 (株)関電工入社。主として架空送電線 工事に関わる工法の研究に従事。現在，同社電力 本部送電線部勤務。 